\title{
Lung transplantation for emphysema
}

\author{
Ilhan Inci \\ Department of Thoracic Surgery, University Hospital, Raemistrasse, Zurich, Switzerland \\ Correspondence to: Ilhan Inci, MD, FCCP, FEBTS. Professor of Thoracic Surgery, Department of Thoracic Surgery, University Hospital, Raemistrasse \\ 100, 8091, Zurich, Switzerland. Email: ilhan.inci@usz.ch.
}

\begin{abstract}
Lung transplantation (LT) is proved to be effective in patients with end-stage lung disease who are failing optimal therapy. Chronic obstructive pulmonary disease (emphysema) is the most common indication for adult lung transplantation. As most patients with emphysema (EMP) can survive long term, it could be difficult to decide which patient should be listed for LT. LT is a complex surgery. Therefore, it is extremely important to choose a recipient in whom expected survival is at less equal or comparable to the survival without surgery. This paper reviews patient selection, bridging strategies until lung transplantation, surgical approach and choice of the procedure, and functional outcome in emphysema recipients.
\end{abstract}

Keywords: Lung transplantation (LT); emphysema (EMP); survival; patient selection

Submitted Jan 15, 2020. Accepted for publication Apr 06, 2020.

doi: 10.21037/atm-20-805

View this article at: http://dx.doi.org/10.21037/atm-20-805

\section{Introduction}

Chronic obstructive pulmonary disease (emphysema) is the leading diagnosis for recipients requiring lung transplantation (LT) (1). Together with alpha 1-antitrypsin deficiency (A1ATD), the rate is about one third of all lung transplantations done (1). In spite of the 63.530 lung transplantations performed, the question regarding the appropriate timing of the procedure in emphysema (EMP) recipients and the type of procedure is still challenging $(1,2)$. This review article includes patient selection, bridging strategies until lung transplantation, surgical approach, and choice of the procedure, and functional outcome in emphysema recipients.

\section{Recipient selection}

Lung transplantation (LT) is proved to be effective in patients with end-stage lung disease who are failing optimal therapy (3). Recipient selection and the timing of LT is an important (4). Most of the transplant centers use the guidelines published by the International Society for Heart and Lung Transplantation (ISHLT), however it may also be done on individual bases (3-5). Because of the natural history of most recipients with EMP, it could be difficult to decide which patient should be listed for LT (4). LT is a complex surgery and like other major surgeries, it might lead to complications and mortality. For this reason, it is extremely important to choose a recipient in whom expected survival is at less equal or comparable to the survival without surgery (4). Forced expiratory volume in 1 second (FEV1) is used as a prognostic indicator for survival of EMP recipients (4). Studies from Vestbo et al. and Nishimura et al. have shown that drop in lung function up to 5 -year period was minimal $(6,7)$. Also, in A1ATD recipients, Seersholm et al. reported 50\% 2-year survival when FEV1 is $15 \%$ (8). On the other hand, degree of airway obstruction is not the only factor that affects the natural history EMP. Age, hypoxemia, hypercapnia, pulmonary hypertension, low body mass index, poor exercise capacity, magnitude of dyspnea, and emphysema severity are reported to be also important risk factors $(2,4,6,9,10)$.

Unfortunately, these factors have limited strength to define the prognosis of a patient. In order to overcome this limitation, Celli et al. have put together those confounders in order to predict outcome in EMP patients (11). They included four factors that might predict an increased risk of death in EMP patients. They named it as BODE index. The factors they used are body mass index (B), airflow 
obstruction measured by FEV1 (O), dyspnea score (D), and exercise capacity measured by 6 -minute walking test (E) (11). This scoring system (BODE Index) ranges from 0 to 10 , with a higher score indicating higher risk of death $(2,11)$. Increase in BODE index greater than 1 point over a 6- to 24-month period reported to double the risk of death (12). The recent ISHLT guidelines published in 2015 includes BODE index in listing patients for EMP (3). BODE index of more than five is recommended for referral $(3,11)$. ISHLT guidelines recommend listing with a BODE score of 7 to 10 or at least one of the following: (I) history of hospitalization for exacerbation associated with acute hypercapnia $\left(\mathrm{pCO}_{2}>50 \mathrm{mmHg}\right)$; (II) pulmonary hypertension and/or cor pulmonale, despite oxygen therapy; or (III) $\mathrm{FEV}_{1}<20 \%$ and either diffusing capacity for carbon monoxide (DLCO) $<20 \%$ or homogeneous distribution of emphysema (3).

Early referral for patients who do not meet above mentioned criteria is also recommended as this might allow the transplant team to identify and address factors that might compromise the future candidacy of the patient, such as ongoing smoking, extremes of weight, poor functional status, severe osteoporosis, excessive corticosteroid use, and coronary artery disease (2).

Lung transplantation is a complex treatment option with a significant risk of perioperative morbidity and mortality. ISHLT guidelines for absolute contraindications are as follows (3): malignancy in the last 2 years, with the exception of cutaneous squamous and basal cell tumors; untreatable advanced dysfunction of another major organ system (e.g., heart, liver, or kidney); non-curable chronic extra-pulmonary infection including chronic active viral hepatitis $\mathrm{B}$, hepatitis $\mathrm{C}$, and human immunodeficiency virus; significant chest wall/spinal deformity; documented nonadherence or inability to follow through with medical therapy or office follow-up, or both; untreatable psychiatric or psychological condition associated with the inability to cooperate or comply with medical therapy; absence of a consistent or reliable social support system; substance addiction (e.g., alcohol, tobacco, or narcotics) that is either active or within the last 6 months.

The widely accepted relative contraindications reported by ISHLT are (3): age older than 65 years, critical or unstable clinical condition, severely limited functional status with poor rehabilitation potential, colonization with highly resistant or highly virulent bacteria, fungi, or mycobacteria, severe obesity defined as a body mass index (BMI) exceeding $30 \mathrm{~kg} / \mathrm{m}^{2}$ (13), severe or symptomatic osteoporosis.

\section{Extracorporeal membrane oxygenation (ECMO) as a bridge to $\mathbf{L T}$}

In EMP patients hypercapnia or hypoxemia will develop despite maximal support and therefore ECMO would be their only chance to survive until a donor lung could be found (14). With the improved knowledge, bridging patients on ECMO is not a contraindication to LT with comparable one-and 2-year survivals to those that underwent LT without preoperative ECMO use (15-18).

\section{Lung volume reduction surgery}

Compared to medical management strategies lung volume reduction surgery (LVRS) and LT have been shown to provide superior survival in selected patients with $\operatorname{EMP}(19,20)$.

Although the experience with LVRS has grown over the last years, the selection of patients for LVRS is still a matter of controversy when the emphysema distribution is not heterogeneous and differs widely among centers (21-25). This concept was first reported by Brantigan (26) and reintroduced by Cooper et al. (27).

For young patients LVRS does not replace the need for LT. However, LVRS is an option for definitive treatment for older patients with significant comorbidities, in whom the transplantation is not indicated.

LT improves the quality of life, however the procedure itself is complex, and requires life-long immunosuppression and confronted to side-effects of these drugs (28).

However, donor shortage is still the main limitation for LT and LVRS is rarely performed (28). In addition, LVRS might be a bridging strategy to LT due to the limited organ pool (29). LVRS is indicated in less advanced lung disease compared to LT candidates. However, there is a group of patients in which both procedures can be offered with improved outcomes (30). Our selection criteria in Zurich for LVRS and/or LT is summarized in Figure 1.

In heterogeneous and in homogenous emphysema relevant symptomatic and functional improvements has been reported. Three to 6 months after operation maximal values were observed with a subsequent decline towards preoperative levels over the following years $(31,32)$. LVRS can be performed in selected patients with advanced EMP who has severe hyperinflation, if the FEV1 and the carbon monoxide diffusing capacity are not below 20\% (30-32).

Discussion continues about the effect of pre-transplant LVRS on outcomes after lung transplantation. Early reports demonstrated comparable outcomes (33-35). 


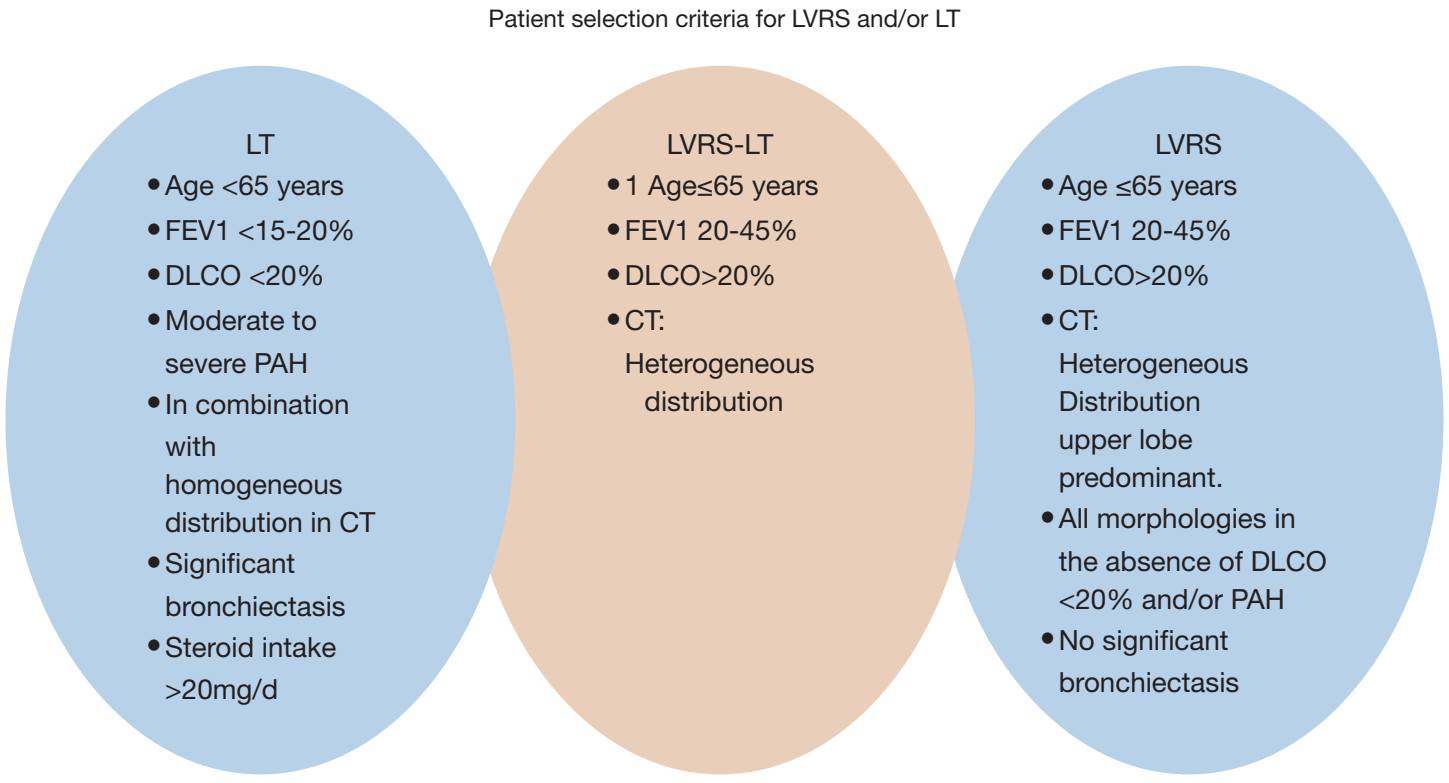

Figure 1 Patient selection criteria in Zurich for LVRS and/or LT based on patients' age, pulmonary function tests, radiologic findings, pulmonary hypertension, and steroid intake. LVRS, lung volume reduction surgery; LT, lung transplantation; PAH, pulmonary hypertension; CT, computed tomography.

The main limitation of these studies were the lack of patient selection criteria. Backhus et al. from University of Washington, Seattle reported inferior results in recipients undergoing LT following LVRS compared to LT alone (36). In this paper 174 patients underwent LT for EMP in 15 years of a period. Among these, 36 had pre-transplantation LVRS. They reported that selecting patients for LT with a history of LVRS requires a careful assessment as those recipients experienced inferior survival after lung transplantation (36).

We recently published our single center experience for patients undergoing LVRS followed by LT ( $\mathrm{n}=52)$ (37). This patient population was, to our knowledge, the largest cohort published so far. We found that outcomes were not different for recipients who underwent combined procedures when compared to recipients who underwent LT only. In addition, Seattle Group reported longer operation times and hospital stays during LT in patients with a history of LVRS (36).

In EMP patients who are potential candidates for LT, LVRS might improve lung function, symptoms and quality of life that might postpone LT for couple of years $(30,37)$. Although there are still concerns (36), previous LVRS had no negative effect on outcome following LT and these patients do not lose their chance for $\operatorname{LT}(30,37)$.

\section{Surgical approach}

Both bilateral lung transplantation (BLT) and single lung transplantation (SLT) can be performed in EMP recipients. Rarely, if severe cardiac pathology presents, heart-lung transplantation can be performed. These patients with secondary pulmonary hypertension can even undergo SLT without any graft dysfunction and with improved pulmonary hemodynamics in the early perioperative period $(38,39)$.

SLT can be performed via antero-lateral or posterolateral thoracotomy incision. BLT was initially performed via clamshell incision (bilateral trans-sternal thoracotomy) (4). Clamshell incision is later replaced by the most centers with bilateral antero-lateral thoracotomy incision without transverse sternotomy (40-42).

\section{Choice of the procedure}

Recent international registry (ISHLT) reported 7.8 years of median survival in recipients that received BLT compared to 4.8 years in SLT recipients (Figure 2) (1). These rates increase to 10.2 years in BLT recipients and 6.5 years in SLT recipients who survive the first year following LT (1).

According to the recent ISHLT registry 22.121 lung transplants were performed for EMP $(\mathrm{N}=19,152)$ and A1ATD $(\mathrm{N}=2,969)$ from January 1995 to June 2018 (1). 


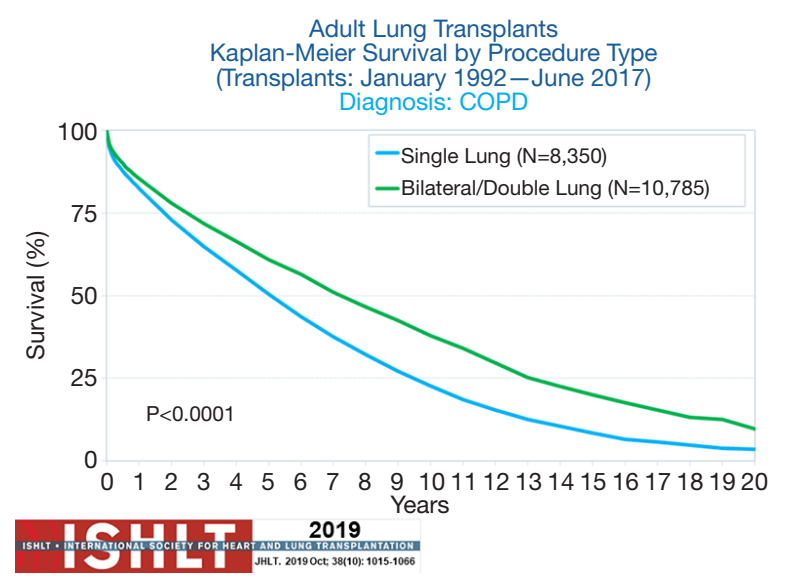

Figure 2 Survival curve in COPD recipients who received bilateral or single lung transplantation from recent international registry (ISHLT) reported 7.8 years of median survival in recipients that received bilateral compared to 4.8 years in single lung transplant recipients. Kaplan-Meier method was used to calculate survival. Survival rates were compared using the log-rank test statistic.

In 2005 , only approximately $50 \%$ of the transplantations performed for EMP were BLT. Thereafter the rate of BLT increased up to $81 \%$ in 2017 (1). Ventilation-perfusion mismatching following single lung transplantation and possible graft dysfunction have influenced the centers not to perform SLT. Stevens et al. demonstrated ventilation and perfusion mismatch in SLT recipients (43). In spite of this report, transplant centers started to perform SLT in the early 90's with good results $(44,45)$.

Majority of the centers prefer BLT, due to complications that might occur from the native lung (45-48). Short total ischemic time and operation time are advantageous of SLT that lead to lower morbidity and mortality (49).

Sunderasan et al. demonstrated the outcomes of their EMP patients who underwent LT (50). They reported comparable outcome in patients received BLT or SLT. 5 -year survival was 53\% in BLT recipients and $41 \%$ in SLT recipients (50). In another study, Cassivi et al. reported 5 -year survival rate of $66.7 \%$ in BLT and $44.9 \%$ in SLT recipients (51) Delgado et al. from Spain demonstrated similar cumulative 5 -year survival rate, excluding preoperative mortality, with 54\% overall, $59 \%$ for SLT and $56 \%$ for BLT. The frequency of BOS was $34 \%$ in SLT and $42 \%$ in BLT. Acute rejection episodes and perioperative complication rates were also comparable between SLT and BLT groups (52).

Survival after both SLT and BLT in EMP patients was analyzed (53). Among included 9883 patients with EMP, 36\% underwent BLT, and 64\% SLT. The median survival after either type of LT for patients with EMP was 5.0 years (95\% CI: 4.8-5.2). The proportion of patients who had BLT increased from $21.6 \%$ in 1993 to $56.2 \%$ in 2006. Median survival time after BLT was longer than that after SLT: 6.4 years $(6.02-6.88)$ versus 4.6 years $(\mathrm{P}<0.0001)$. This study showed that BLT did not have survival advantage in patients over 60 years of age at transplantation. The authors stated that BLT gives longer survival compared to SLT and in recipients who are younger than 60 years of age (53).

Meyer et al. studied 2,260 lung transplant recipients who underwent lung transplantation for EMP (54). 30 -day, 1 year, and 5 years survival (\%) in patients aged $<50$ years were 93.6, 80.2, and 43.6, respectively, for the SLT patients, and 94.9, 84.7, and 68.2, respectively in BLT cases. For patients aged 50 to 60 years, survival rates (\%) were 93.5, 79.4, and 39.8 for the SLT patients compared with 93.0, 79.7, and 60.5 for the BLT patients. Recipients aged $>60$ years, survival (\%) was 93.0, 72.9, and 36.4 in SLT, compared to 77.8 and 66.0 in BLT. The multivariate model showed a higher risk ratio for mortality in patients aged 40 to 57 years who received SLT versus BLT. They stated that SLT might offer acceptable early survival for patients with end-stage respiratory failure. However, long-term survival data favors BLT in recipients younger than 60 years-old. Their data suggest that BLT approach offers a significant survival advantage to recipients younger than 60 years of age (54). In our recent publication, we demonstrated that 5 -year survival rate for those $<60$ years old was significantly better than those of $\geq 60$ years ( $84 \%$ and $54 \%, \mathrm{P}=0.05$ ) (47).

A multicenter study showed that BLT was superior to SLT (55). Based on these studies, BLT has similar shortterm results compared with SLT, but better long-term results (56).

There are also other reasons why the transplant community prefer to perform BLT instead of SLT in EMP recipients (56). Hyperinflation of the native lung, which was reported to be between $5 \%$ to $15 \%$ of cases, is one of the reasons (45,57-59). Native lung pneumonia (10\% to $20 \%$ ) may lead to $20 \%$ of mortality rate $(60,61)$. In $3 \%$ of the recipients lung cancer can occur in the native lung $(62,63)$.

\section{Functional outcomes}

Following LT physiologic parameters like FEV1 and FVC improve in EMP recipients (64). Cases who undergo BLT show much more improvement. After SLT, FEV1 increases 
to $60 \%$, whereas the FEV1 exceeds $80 \%$ in $\operatorname{BLT}(50,65,66)$.

$6 \mathrm{MWT}$ distance did not show significant difference in daily physical activity between the SLT and BLT among recipients $(67,68)$.

In addition, exercise performance as assessed by the ageadjusted parameter of maximum oxygen consumption was also comparable between SLT and BLT $(69,70)$.

The type of the procedure and development of bronchiolitis obliterans syndrome (BOS) attracted the attention of several investigators. These studies failed to detect a difference in incidence of bronchiolitis obliterans syndrome (BOS) among recipients of SLT versus BLT $(44,50,66)$. On the other hand, increased freedom from BOS in BLT recipients was reported at both 3 and 5 years following LT (71).

\section{Conclusion}

Careful patient selection and to offer the best surgical option are extremely important to reach successful outcomes in emphysema patients. Lung transplantation is an option for those who have failed optimal medical treatment. LVRS postpones the need for LT for up to several years and leads to improvement in nutritional and functional status until LT. LVRS does not compromise the outcome in case of future LT. Bilateral LT offers the best long-term outcome in these patients.

\section{Acknowledgments}

Funding: None.

\section{Footnote}

Provenance and Peer Review: This article was commissioned by the Guest Editor (Bassam Redwan) for the series "Lung Emphysema" published in Annals of Translational Medicine. The article was sent for external peer review organized by the Guest Editor and the editorial office.

Conflicts of Interest: The author has completed the ICMJE uniform disclosure form (available at http://dx.doi. org/10.21037/atm-20-805). The author has no conflicts of interest to declare.

Ethical Statement: The author is accountable for all aspects of the work in ensuring that questions related to the accuracy or integrity of any part of the work are appropriately investigated and resolved.

Open Access Statement: This is an Open Access article distributed in accordance with the Creative Commons Attribution-NonCommercial-NoDerivs 4.0 International License (CC BY-NC-ND 4.0), which permits the noncommercial replication and distribution of the article with the strict proviso that no changes or edits are made and the original work is properly cited (including links to both the formal publication through the relevant DOI and the license). See: https://creativecommons.org/licenses/by-nc-nd/4.0/.

\section{References}

1. Chambers DC, Cherikh WS, Harhay MO, et al. The International Thoracic Organ Transplant Registry of the International Society for Heart and Lung Transplantation: Thirty-sixth adult lung and heart-lung transplantation Report-2019; Focus theme: Donor and recipient size match. J Heart Lung Transplant 2019;38:1042-55.

2. Shah RJ, Kotloff RM. Lung transplantation for obstructive lung diseases. Semin Respir Crit Care Med 2013;34:288-96.

3. Weill D, Benden C, Corris PA, et al. A consensus document for the selection of lung transplant candidates: 2014--an update from the Pulmonary Transplantation Council of the International Society for Heart and Lung Transplantation. J Heart Lung Transplant 2015;34:1-15.

4. Patel N, Criner GJ. Transplantation in chronic obstructive pulmonary disease. COPD 2006;3:149-62.

5. International guidelines for the selection of lung transplant candidates. The American Society for Transplant Physicians (ASTP)/American Thoracic Society(ATS)/ European Respiratory Society(ERS)/International Society for Heart and Lung Transplantation(ISHLT). Am J Respir Crit Care Med 1998;158:335-9.

6. Vestbo J, Edwards LD, Scanlon PD, et al. Changes in forced expiratory volume in 1 second over time in COPD. N Engl J Med 2011;365:1184-92.

7. Nishimura M, Makita H, Nagai K, et al. Annual change in pulmonary function and clinical phenotype in chronic obstructive pulmonary disease. Am J Respir Crit Care Med 2012;185:44-52.

8. Seersholm N, Kok-Jensen A, Dirksen A. Survival of patients with severe alpha 1-antitrypsin deficiency with special reference to non-index cases. Thorax 1994;49:695-8.

9. Martinez FJ, Kotloff R. Prognostication in chronic 
obstructive pulmonary disease: implications for lung transplantation. Semin Respir Crit Care Med 2001;22:489-98.

10. Traver GA, Cline MG, Burrows B. Predictors of mortality in chronic obstructive pulmonary disease. A 15-year follow-up study. Am Rev Respir Dis 1979;119:895-902.

11. Celli BR, Cote CG, Marin JM, et al. The body-mass index, airflow obstruction, dyspnea, and exercise capacity index in chronic obstructive pulmonary disease. N Engl J Med 2004;350:1005-12.

12. Martinez FJ, Han MK, Andrei AC, et al. Longitudinal change in the BODE index predicts mortality in severe emphysema. Am J Respir Crit Care Med 2008;178:491-9.

13. Kanasky WF, Jr., Anton SD, Rodrigue JR, et al. Impact of body weight on long-term survival after lung transplantation. Chest 2002;121:401-6.

14. Cypel M, Keshavjee S. Extracorporeal life support as a bridge to lung transplantation. Clin Chest Med 2011;32:245-51.

15. Fuehner T, Kuehn C, Hadem J, et al. Extracorporeal membrane oxygenation in awake patients as bridge to lung transplantation. Am J Respir Crit Care Med 2012;185:763-8.

16. Lafarge M, Mordant P, Thabut G, et al. Experience of extracorporeal membrane oxygenation as a bridge to lung transplantation in France. J Heart Lung Transplant 2013;32:905-13.

17. Toyoda Y, Bhama JK, Shigemura N, et al. Efficacy of extracorporeal membrane oxygenation as a bridge to lung transplantation. J Thorac Cardiovasc Surg 2013;145:1065-71.

18. Inci I, Klinzing S, Schneiter D, et al. Outcome of Extracorporeal Membrane Oxygenation as a Bridge To Lung Transplantation: An Institutional Experience and Literature Review. Transplantation 2015;99:1667-71.

19. Marchetti N, Criner GJ. Surgical Approaches to Treating Emphysema: Lung Volume Reduction Surgery, Bullectomy, and Lung Transplantation. Semin Respir Crit Care Med 2015;36:592-608.

20. Weder W, Thurnheer R, Stammberger U, et al. Radiologic emphysema morphology is associated with outcome after surgical lung volume reduction. Ann Thorac Surg 1997;64:313-9; discussion 319-20.

21. Ciccone AM, Meyers BF, Guthrie TJ, et al. Longterm outcome of bilateral lung volume reduction in 250 consecutive patients with emphysema. J Thorac Cardiovasc Surg 2003;125:513-25.

22. Criner GJ, Cordova FC, Furukawa S, et al. Prospective randomized trial comparing bilateral lung volume reduction surgery to pulmonary rehabilitation in severe chronic obstructive pulmonary disease. Am J Respir Crit Care Med 1999;160:2018-27.

23. Fujimoto T, Teschler H, Hillejan L, et al. Longterm results of lung volume reduction surgery. Eur J Cardiothorac Surg 2002;21:483-8.

24. Pompeo E, Marino M, Nofroni I, et al. Reduction pneumoplasty versus respiratory rehabilitation in severe emphysema: a randomized study. Pulmonary Emphysema Research Group. Ann Thorac Surg 2000;70:948-53; discussion 954.

25. Weder W, Tutic M, Bloch KE. Lung volume reduction surgery in nonheterogeneous emphysema. Thorac Surg Clin 2009;19:193-9.

26. Brantigan OC, Mueller E, Kress MB. A surgical approach to pulmonary emphysema. Am Rev Respir Dis 1959;80:194-206.

27. Cooper JD, Patterson GA, Sundaresan RS, et al. Results of 150 consecutive bilateral lung volume reduction procedures in patients with severe emphysema. J Thorac Cardiovasc Surg 1996;112:1319-29; discussion 1329-30.

28. Trotter MA, Hopkins PM. Advanced therapies for COPDWhat's on the horizon? Progress in lung volume reduction and lung transplantation. J Thorac Dis 2014;6:1640-53.

29. Kostron A, Horn-Tutic M, Franzen D, et al. Repeated lung volume reduction surgery is successful in selected patients. Eur J Cardiothorac Surg 2015;48:710-5.

30. Tutic M, Lardinois D, Imfeld S, et al. Lung-volume reduction surgery as an alternative or bridging procedure to lung transplantation. Ann Thorac Surg 2006;82:208-13; discussion 213.

31. Bloch KE, Georgescu CL, Russi EW, et al. Gain and subsequent loss of lung function after lung volume reduction surgery in cases of severe emphysema with different morphologic patterns. J Thorac Cardiovasc Surg 2002;123:845-54.

32. Weder W, Tutic M, Lardinois D, et al. Persistent benefit from lung volume reduction surgery in patients with homogeneous emphysema. Ann Thorac Surg 2009;87:22936; discussion 236-7.

33. Burns KE, Keenan RJ, Grgurich WF, et al. Outcomes of lung volume reduction surgery followed by lung transplantation: a matched cohort study. Ann Thorac Surg 2002;73:1587-93.

34. Nathan SD, Edwards LB, Barnett SD, et al. Outcomes of COPD lung transplant recipients after lung volume reduction surgery. Chest 2004;126:1569-74. 
35. Senbaklavaci O, Wisser W, Ozpeker C, et al. Successful lung volume reduction surgery brings patients into better condition for later lung transplantation. Eur J Cardiothorac Surg 2002;22:363-7.

36. Backhus L, Sargent J, Cheng A, et al. Outcomes in lung transplantation after previous lung volume reduction surgery in a contemporary cohort. J Thorac Cardiovasc Surg 2014;147:1678-83 e1.

37. Inci I, Iskender I, Ehrsam J, et al. Previous lung volume reduction surgery does not negatively affect survival after lung transplantation. Eur J Cardiothorac Surg 2018;53:596-602.

38. Bjortuft O, Simonsen S, Geiran OR, et al. Pulmonary haemodynamics after single-lung transplantation for end-stage pulmonary parenchymal disease. Eur Respir J 1996;9:2007-11.

39. Boujoukos AJ, Martich GD, Vega JD, et al. Reperfusion injury in single-lung transplant recipients with pulmonary hypertension and emphysema. J Heart Lung Transplant 1997;16:439-48.

40. Kaiser LR, Pasque MK, Trulock EP, et al. Bilateral sequential lung transplantation: the procedure of choice for double-lung replacement. Ann Thorac Surg 1991;52:43845; discussion 445-6.

41. Meyers BF, Sundaresan RS, Guthrie T, et al. Bilateral sequential lung transplantation without sternal division eliminates posttransplantation sternal complications. J Thorac Cardiovasc Surg 1999;117:358-64.

42. Taghavi S, Birsan T, Seitelberger R, et al. Initial experience with two sequential anterolateral thoracotomies for bilateral lung transplantation. Ann Thorac Surg 1999;67:1440-3.

43. Stevens PM, Johnson PC, Bell RL, et al. Regional ventilation and perfusion after lung transplantation in patients with emphysema. N Engl J Med 1970;282:245-9.

44. Levine SM, Anzueto A, Peters JI, et al. Medium term functional results of single-lung transplantation for endstage obstructive lung disease. Am J Respir Crit Care Med 1994;150:398-402.

45. Mal H, Brugiere O, Sleiman C, et al. Morbidity and mortality related to the native lung in single lung transplantation for emphysema. J Heart Lung Transplant 2000;19:220-3.

46. Venuta F, Boehler A, Rendina EA, et al. Complications in the native lung after single lung transplantation. Eur J Cardiothorac Surg 1999;16:54-8.

47. Inci I, Schuurmans M, Ehrsam J, et al. Lung transplantation for emphysema: impact of age on short- and long-term survival. Eur J Cardiothorac Surg 2015;48:906-9.

48. Inci I, Schuurmans MM, Boehler A, et al. Zurich University Hospital lung transplantation programme: update 2012. Swiss Med Wkly 2013;143:w13836.

49. Aziz F, Penupolu S, Xu X, et al. Lung transplant in endstaged chronic obstructive pulmonary disease (COPD) patients: a concise review. J Thorac Dis 2010;2:111-6.

50. Sundaresan RS, Shiraishi Y, Trulock EP, et al. Single or bilateral lung transplantation for emphysema? J Thorac Cardiovasc Surg 1996;112:1485-94; discussion 94-5.

51. Cassivi SD, Meyers BF, Battafarano RJ, et al. Thirteenyear experience in lung transplantation for emphysema. Ann Thorac Surg 2002;74:1663-9; discussion 9-70.

52. Delgado M, Borro JM, De La Torre MM, et al. Lung transplantation as the first choice in emphysema. Transplant Proc 2009;41:2207-9.

53. Thabut G, Christie JD, Ravaud P, et al. Survival after bilateral versus single lung transplantation for patients with chronic obstructive pulmonary disease: a retrospective analysis of registry data. Lancet 2008;371:744-51.

54. Meyer DM, Bennett LE, Novick RJ, et al. Single vs bilateral, sequential lung transplantation for end-stage emphysema: influence of recipient age on survival and secondary end-points. J Heart Lung Transplant 2001;20:935-41.

55. Hadjiliadis D, Chaparro C, Gutierrez C, et al. Impact of lung transplant operation on bronchiolitis obliterans syndrome in patients with chronic obstructive pulmonary disease. Am J Transplant 2006;6:183-9.

56. Hadjiliadis D, Angel LF. Controversies in lung transplantation: are two lungs better than one? Semin Respir Crit Care Med 2006;27:561-6.

57. Malchow SC, McAdams HP, Palmer SM, et al. Does hyperexpansion of the native lung adversely affect outcome after single lung transplantation for emphysema? Preliminary findings. Acad Radiol 1998;5:688-93.

58. Moy ML, Loring SH, Ingenito EP, et al. Causes of allograft dysfunction after single lung transplantation for emphysema: extrinsic restriction versus intrinsic obstruction. Brigham and Women's Hospital Lung Transplantation Group. J Heart Lung Transplant 1999; 18:986-93.

59. Weill D, Torres F, Hodges TN, et al. Acute native lung hyperinflation is not associated with poor outcomes after single lung transplant for emphysema. J Heart Lung Transplant 1999;18:1080-7.

60. Lingaraju R, Blumenthal NP, Kotloff RM, et al. Effects of 
lung allocation score on waiting list rankings and transplant procedures. J Heart Lung Transplant 2006;25:1167-70.

61. McAdams HP, Erasmus JJ, Palmer SM. Complications (excluding hyperinflation) involving the native lung after single-lung transplantation: incidence, radiologic features, and clinical importance. Radiology 2001;218:233-41.

62. Collins J, Kazerooni EA, Lacomis J, et al. Bronchogenic carcinoma after lung transplantation: frequency, clinical characteristics, and imaging findings. Radiology 2002;224:131-8.

63. von Boehmer L, Draenert A, Jungraithmayr W, et al. Immunosuppression and lung cancer of donor origin after bilateral lung transplantation. Lung Cancer 2012;76:118-22.

64. Mora JI, Hadjiliadis D. Lung volume reduction surgery and lung transplantation in chronic obstructive pulmonary disease. Int J Chron Obstruct Pulmon Dis 2008;3:629-35.

65. Gaissert HA, Trulock EP, Cooper JD, et al. Comparison of early functional results after volume reduction or lung transplantation for chronic obstructive pulmonary disease. J Thorac Cardiovasc Surg 1996;111:296-306; discussion 307.

Cite this article as: Inci I. Lung transplantation for emphysema. Ann Transl Med 2020;8(21):1473. doi: 10.21037/atm-20-805
66. Pochettino A, Kotloff RM, Rosengard BR, et al. Bilateral versus single lung transplantation for chronic obstructive pulmonary disease: intermediate-term results. Ann Thorac Surg 2000;70:1813-8; discussion 1818-9.

67. Bossenbroek L, ten Hacken NH, van der Bij W, et al. Cross-sectional assessment of daily physical activity in chronic obstructive pulmonary disease lung transplant patients. J Heart Lung Transplant 2009;28:149-55.

68. Gerbase MW, Spiliopoulos A, Rochat T, et al. Healthrelated quality of life following single or bilateral lung transplantation: a 7-year comparison to functional outcome. Chest 2005;128:1371-8.

69. Levy RD, Ernst P, Levine SM, et al. Exercise performance after lung transplantation. J Heart Lung Transplant 1993;12:27-33.

70. Williams TJ, Patterson GA, McClean PA, et al. Maximal exercise testing in single and double lung transplant recipients. Am Rev Respir Dis 1992;145:101-5.

71. Hadjiliadis D, Davis RD, Palmer SM. Is transplant operation important in determining posttransplant risk of bronchiolitis obliterans syndrome in lung transplant recipients? Chest 2002;122:1168-75. 